\title{
Comparative analysis of sonic and neutron-density logs for porosity determination in the South-eastern Niger Delta Basin, Nigeria
}

\author{
O. I. Horsfall, E. D. Uko, and I. Tamunobereton-ari \\ Department of Physics, Rivers State University of Science and Technology, \\ PMB 5080, Port Harcourt, Nigeria \\ Corresponding Author: E. D. Uko (e_uko@yahoo.com)
}

\begin{abstract}
A comparative analysis of porosity values computed from sonic and neutron-density logs obtained from the same well is here presented. The aim is to identify the more reliable logging tool between sonic and neutron-density in the estimation of porosity values in a formation. Two wells from different parts of Niger Delta were logged for Transit times, bulk density and hydrogen index of the formation as a function of depth. The analysis of sonic, density and neutron porosity values shows a conventional trend of decrease in porosity with depth. Sonic porosity values of well $A$, and well $B$ varies from 1 to $17 \%$, and 27 to $60 \%$ respectively while Neutron-Density Porosity values of well $A$, and well B varies from 24 to $45 \%$, and 21 to $37 \%$ respectively. The Coefficient of Variation for sonic porosity data are $56 \%$, and $23 \%$ of well A, and well B respectively , similarly the Coefficient of Variation for Neutron-Density porosity data are $15 \%$, and $14 \%$ of well $A$, and well B respectively. Coefficient of variation of Neutron-density log derived porosities is less than sonic log derived porosities; therefore Neutron-density log derived porosity is more reliable tool for porosity data estimation than sonic log derived porosity. Neutron and density logging tool is here recommended for determination of a reliable porosity value of a formation.
\end{abstract}

Keywords: Porosity, rock matrix, standard deviation, coefficient of variation, sonic log, density log, Niger Delta, Nigeria

\section{INTRODUCTION}

Advances in the study of petrophysical parameters have led to enhanced formation evaluation capabilities, identification and quantification of hydrocarbon. Also the potential and performance of a reservoir rock depends on these parameters and certain characteristic properties. These properties include: Porosity $(\phi)$, Permeability $(\mathrm{k})$, Water saturation $\left(\mathrm{S}_{\mathrm{W}}\right)$, grain size, grain shape, degree of compaction, cementation and amount of matrix. The two essential attributes of any reservoir are porosity and permeability.

Porosity can be defined as the fractional/percentage of the total volume occupied by pores or void. It indicates how much fluid a rock can hold. Generally, reservoirs have porosity values within the range of $5 \%$ to $30 \%$, however majority of the reservoirs have porosity values between $10 \%$ and $20 \%$ (Selley and Morrill, 1983). Porosity can be measured from cores in the laboratory and also in a borehole using well logs.

A well log is a continuous recording of one or more geophysical parameters as a function of depth. The objective of well logging is to measure the physical properties of the undisturbed rocks and the fluid content. Petrophysical parameters computed from these logs are radioactivity, electron density, liquidfilled porosity containing hydrogen, sonic transit times and lithology.

Sonic log shows a formation's interval transit time designated as $\Delta \mathrm{t}_{\text {log }}$ (the time in microseconds for an acoustic wave to travel through one foot of a formation along a path parallel to the borehole). Specific acoustic time measurements have been related to porosity of the subsurface formations. The interval transit time for an acoustic wave to travel through the formation is dependent upon lithology and porosity. This enables porosity derivable using sonic log.

Density logging employs the physical principle of gamma ray scattering as a function of bulk density of an environment irradiated by a gamma ray source. It shows a continuous recording of the election density of the formation. Its deficiency arises from the fact, that it only measures the primary and secondary porosity. 
Neutron logs respond primarily to the amount of hydrogen (hydrogen index) in the formation. Thus, in clean formations whose pores are filled with water or oil, the neutron log reflects the amount of liquid filled porosity.

\section{MATERIALS AND METHODS}

Data from two exploratory well logs A \& B from multinational oil company operating within the Niger Delta was used for this research. These well logs specifically Sonic log, Density log and Neutron log were used to compute porosity values Determination of porosity values was achieved by digitizing the sonic and neutron-density logs. Travel times, bulk densities and liquid filled porosity (hydrogen Index of the formation) were digitized every 10 meters interval to the bottom of the wells $A \& B$.

Sonic log-derived porosity: The sonic tool measures the time it takes sound pulses to travel through the formation $\left(\Delta \mathrm{t}_{\mathrm{log}}\right)$. This time is referred to as the interval transit time, or slowness and it is the reciprocal of velocity of the sound wave. The interval transit time of a given formation is dependent on the Lithology elastic properties of the rock matrix, the property of the fluid in the rock, and porosity. Therefore a formation's matrix velocity must be known to derive sonic porosity either by chart or by using formula. The unit of $\Delta \mathrm{t}_{\mathrm{log}}$ is usually in $\mu \mathrm{s} / \mathrm{ft}$ or $\mu \mathrm{s} / \mathrm{m}$ (microseconds per foot or/per metre) and the logs are normally recorded on track 3 , on a linear scale.

Integrated sonic logs can also be useful in interpreting seismic records, and can be very invaluable in the time to depth conversion of seismic data.

Wyllie et al. proposed that the interval transit time $(\Delta t)$ can be represented as the sum of the transit time in the matrix fraction $\left(\Delta t_{m a}\right)$ and the transit time in the liquid fraction $\left(\Delta t_{f}\right)$ thus

$$
\Delta t=(1-\phi) \Delta t_{m a}+\phi \Delta t_{f}
$$

Re-arranging eq. 1becomes:

$$
\phi_{s}=\frac{\Delta t-\Delta t_{m a}}{\Delta t_{f}-\Delta t_{m a}}
$$

In Equation (2), $\phi_{s}=$ sonic-derived porosity; $\Delta t=$ acoustic transit time digitized from the sonic log in $\mu \mathrm{s} / \mathrm{ft} ; \Delta t_{f}=$ fluid transit time $(189 \mu \mathrm{s} / \mathrm{ft}) ;$ and $\Delta t_{m a}=$ transit time for the rock matrix $(55.5 \mu \mathrm{s} / \mathrm{ft})$.
Density log-derived porosity: The density log records a formation's bulk density. This is essentially the overall density of a rock including solid matrix and the fluid enclosed in the pores. The log is scaled linearly in bulk density $\left(\mathrm{g} / \mathrm{cm}^{3}\right)$ and includes a correction curve that indicates the degree of compensation applied to the bulk density data. Density logging is based on the physical phenomenon of gamma ray scattering as a function of the bulk density of an environment irradiated by a gamma ray source. The density log can be used quantitatively, to calculate porosity and indirectly to determine hydrocarbon density. It is also useful in calculation of acoustic impedance. Qualitatively, it is useful as a Lithology indicator, as well as identification of certain minerals, assessment of source rock organic matter content and identification of overpressure and fracture porosity.

The formation bulk density is related to formation matrix density $\left(\rho_{\text {ma }}\right)$ and formation fluid density $\left(\rho_{f}\right)$ as:

$$
\rho=(1-\phi) \rho_{m a}+\phi \rho_{f}
$$

Re-arranging eq. (3), we have:

$$
\phi_{d}=\frac{\rho_{m a}-\rho_{b}}{\rho_{m a}-\rho_{f}}
$$

In Eq. (4) $\phi_{d}=$ density-derived porosity; $\rho_{m a}=$ matrix density $\left(2.648 \mathrm{gcm}^{-3}\right) ; \rho_{b}=$ bulk density (clean liquid filled formation); and $\rho_{f}=$ fluid density $\left(0.89 \mathrm{gcm}^{-3}\right)$. The porosity data obtained from density logs are considered to be total porosity.

Neutron-density derived porosity: The neutron porosity values and density porosity values were used to compute neutron-density porosity using the relation:

$$
\phi_{N D}=\frac{\phi_{N}+\phi_{D}}{2}
$$

where, $\phi_{N}=$ Neutron porosity, $\phi_{D}=$ Density porosity, $\phi_{N D}=$ Neutron-Density porosity.

\section{RESULTS AND DISCUSSION}

Numerical data obtained from the two wells are given by Tables $1 \& 2$ showing the depth, interval travel times, sonic-derived porosities, bulk densities, and density-derived porosities. Transit time was shown to be decreasing with an increasing depth for the two wells but varies at some depth due to changes in lithology, vuggy pores and abnormal pressure zone; 
this is shown in Figs. 1 and 7. Similarly Figs. 2, 3, 4, $5,8,9,10$ and 11 showed trends of decreasing porosity with an increase in depth; attributed to the compactness of formation. Though, these trends are not linear with scattered point; these observations phenomena are perhaps due to changes in lithological characteristics at different depth points. Also Figs. 6 and 12 shows the plot of sonic derived porosities against neutron-density derived porosities, from the plot it was observed that there is high degree of correlation between the sonic derived porosity and neutron-density porosity. Tables 3-6 show the results of the statistical analysis. Table 7 shows the computed range, mean porosity values, standard deviation and coefficient of variation for both wells $A$ and $B$.

Table 1: Depth, Interval Transit time, sonic-derived porosity, bulk densities, density-derived porosity, neutron-derived porosity, and neutron-density derived porosity relationship for well $\mathbf{A}$.

\begin{tabular}{|c|c|c|c|c|c|c|}
\hline $\operatorname{Depth}(\mathrm{m})$ & $\begin{array}{l}\text { Transit time } \\
\times 10^{-6}(\mathrm{~s} / \mathrm{m})\end{array}$ & $\begin{array}{c}\text { Sonic } \\
\text { Porosity (\%) }\end{array}$ & $\begin{array}{c}\text { Bulk } \\
\text { Density } \\
\times 10^{3}\left(\mathrm{~kg} / \mathrm{m}^{3}\right)\end{array}$ & $\begin{array}{c}\text { Density } \\
\text { porosity (\%) }\end{array}$ & $\begin{array}{c}\text { Neutron } \\
\text { Porosity (\%) }\end{array}$ & $\begin{array}{c}\text { Neutron- } \\
\text { density } \\
\text { porosity (\%) }\end{array}$ \\
\hline 1200 & 207 & 6 & 2.20 & 27 & 31 & 29.0 \\
\hline 1210 & 226 & 10 & 2.09 & 34 & 30 & 32.0 \\
\hline 1220 & 230 & 11 & 2.09 & 34 & 33 & 33.5 \\
\hline 1230 & 223 & 9 & 2.06 & 36 & 32 & 34.0 \\
\hline 1240 & 210 & 6 & 2.13 & 32 & 26 & 29.0 \\
\hline 1250 & 197 & 3 & 2.13 & 32 & 25 & 28.5 \\
\hline 1260 & 216 & 8 & 2.05 & 36 & 31 & 33.5 \\
\hline 1270 & 226 & 10 & 2.07 & 35 & 34 & 34.5 \\
\hline 1280 & 233 & 12 & 2.05 & 36 & 32 & 34.0 \\
\hline 1290 & 213 & 7 & 2.10 & 33 & 31 & 32.0 \\
\hline 1300 & 243 & 14 & 2.01 & 39 & 36 & 37.5 \\
\hline 1310 & 200 & 4 & 2.16 & 30 & 29 & 29.5 \\
\hline 1320 & 223 & 9 & 2.09 & 34 & 31 & 32.5 \\
\hline 1330 & 226 & 10 & 2.09 & 34 & 37 & 35.5 \\
\hline 1340 & 203 & 5 & 2.23 & 25 & 35 & 30.0 \\
\hline 1350 & 220 & 12 & 2.08 & 35 & 34 & 34.5 \\
\hline 1360 & 220 & 9 & 2.19 & 28 & 32 & 30.0 \\
\hline 1370 & 253 & 16 & 1.94 & 43 & 40 & 41.5 \\
\hline 1380 & 230 & 11 & 2.02 & 38 & 37 & 37.5 \\
\hline 1390 & 223 & 9 & 2.10 & 33 & 28 & 30.5 \\
\hline 1400 & 213 & 7 & 2.15 & 30 & 27 & 28.5 \\
\hline 1410 & 203 & 5 & 2.16 & 30 & 28 & 29.0 \\
\hline 1420 & 213 & 7 & 2.15 & 30 & 28 & 29.0 \\
\hline 1430 & 216 & 8 & 2.14 & 31 & 36 & 33.5 \\
\hline 1440 & 203 & 5 & 2.21 & 27 & 29 & 28.0 \\
\hline 1450 & 203 & 5 & 2.17 & 29 & 27 & 28.0 \\
\hline 1460 & 207 & 6 & 2.19 & 28 & 25 & 26.5 \\
\hline 1470 & 194 & 3 & 2.18 & 28 & 30 & 29.0 \\
\hline 1480 & 203 & 5 & 2.19 & 28 & 27 & 27.5 \\
\hline 1490 & 210 & 6 & 2.14 & 31 & 28 & 29.5 \\
\hline
\end{tabular}


Table 2: Depth, Interval Transit time, sonic - derived porosity, bulk densities, density-derived porosity, neutron-derived porosity, and neutron-density derived porosity relationship for well B.

\begin{tabular}{|c|c|c|c|c|c|c|}
\hline Depth (m) & $\begin{array}{c}\text { Transit } \\
\text { time } \\
\times 10^{-6}(\mathrm{~s} / \mathrm{m})\end{array}$ & $\begin{array}{c}\text { Sonic Porosity } \\
(\%)\end{array}$ & $\begin{array}{c}\text { Density } \\
\times 10^{3}\left(\mathrm{~kg} / \mathrm{m}^{3}\right)\end{array}$ & $\begin{array}{l}\text { Density } \\
\text { porosity } \\
(\%)\end{array}$ & $\begin{array}{c}\text { Neutron } \\
\text { Porosity (\%) }\end{array}$ & $\begin{array}{l}\text { Neutron- } \\
\text { density } \\
\text { porosity (\%) }\end{array}$ \\
\hline 1160 & 426 & 56 & 2.06 & 36 & 36 & 36.0 \\
\hline 1170 & 443 & 60 & 2.04 & 37 & 39 & 38.0 \\
\hline 1180 & 426 & 56 & 2.05 & 36 & 37 & 36.5 \\
\hline 1190 & 443 & 60 & 2.05 & 36 & 35 & 35.5 \\
\hline 1200 & 426 & 56 & 2.15 & 30 & 33 & 31.5 \\
\hline 1210 & 440 & 59 & 2.07 & 35 & 34 & 34.5 \\
\hline 1220 & 436 & 58 & 2.07 & 35 & 36 & 35.5 \\
\hline 1230 & 413 & 53 & 2.16 & 30 & 36 & 33.0 \\
\hline 1240 & 394 & 48 & 2.07 & 35 & 33 & 34.0 \\
\hline 1250 & 394 & 48 & 2.05 & 36 & 37 & 36.5 \\
\hline 1260 & 361 & 41 & 2.15 & 30 & 32 & 31.0 \\
\hline 1270 & 367 & 42 & 2.05 & 36 & 32 & 34.0 \\
\hline 1280 & 371 & 43 & 2.03 & 38 & 32 & 35.0 \\
\hline 1290 & 351 & 39 & 2.07 & 35 & 27 & 31.0 \\
\hline 1300 & 367 & 42 & 2.07 & 35 & 32 & 33.5 \\
\hline 1310 & 335 & 35 & 2.20 & 27 & 30 & 28.5 \\
\hline 1320 & 358 & 40 & 2.11 & 33 & 28 & 30.5 \\
\hline 1330 & 371 & 43 & 2.07 & 35 & 33 & 34.0 \\
\hline 1340 & 377 & 45 & 2.07 & 35 & 31 & 33.0 \\
\hline 1350 & 367 & 42 & 2.10 & 33 & 33 & 33.0 \\
\hline 1360 & 394 & 48 & 2.21 & 27 & 34 & 30.5 \\
\hline 1370 & 354 & 39 & 2.07 & 35 & 31 & 33.0 \\
\hline 1380 & 361 & 41 & 2.10 & 33 & 31 & 32.0 \\
\hline 1390 & 371 & 43 & 2.06 & 36 & 33 & 34.5 \\
\hline 1400 & 348 & 38 & 2.11 & 33 & 33 & 33.0 \\
\hline 1410 & 364 & 42 & 2.14 & 31 & 24 & 27.5 \\
\hline 1420 & 328 & 33 & 2.24 & 25 & 30 & 27.5 \\
\hline 1430 & 308 & 29 & 2.25 & 24 & 20 & 22.0 \\
\hline 1440 & 295 & 26 & 2.25 & 24 & 18 & 21.0 \\
\hline 1450 & 318 & 31 & 2.20 & 27 & 24 & 25.5 \\
\hline
\end{tabular}

Table 3:

Statistical table showing the calculation of Standard deviation for Sonic Log of Well A

\begin{tabular}{|c|c|c|c|c|c|c|c|}
\hline $\begin{array}{c}\text { Class } \\
\text { Interval (\%) }\end{array}$ & $\begin{array}{c}\text { Frequency } \\
\mathrm{F}\end{array}$ & $\phi_{\text {son }}(\%)$ & $\mathrm{F} \phi_{\text {son }}(\%)$ & $\begin{array}{c}\bar{\phi}_{\text {sonic }} \\
(\%)\end{array}$ & $\begin{array}{c}\left(\phi_{\text {son }}-\bar{\phi}_{\text {son }}\right) \\
(\%)\end{array}$ & $\begin{array}{c}\left(\phi_{\text {son }-\bar{\phi}} \text { son }\right)^{2} \\
\left(\%^{2}\right)\end{array}$ & $\begin{array}{c}F_{\left(\phi_{\text {son }}-\right.} \\
\left.\bar{\phi}_{\text {son }}\right)^{2}\left(\%^{2}\right)\end{array}$ \\
\hline \hline $0-4$ & 36 & 2 & 72 & 6.96 & -4.69 & 21.9961 & 791.860 \\
\hline $5-9$ & 64 & 7 & 448 & 6.96 & 0.04 & 0.0016 & 0.102 \\
\hline $10-14$ & 27 & 12 & 324 & 6.96 & 5.04 & 25.4016 & 685.843 \\
\hline $15-19$ & 4 & 17 & 68 & 6.96 & 10.04 & 100.8016 & 403.206 \\
\hline & $\begin{array}{c}\sum \mathrm{F} \\
=131\end{array}$ & $\begin{array}{c}\sum \mathrm{F} \phi_{\text {son }} \\
=912\end{array}$ & & & & $\begin{array}{c}\sum \mathrm{F}\left(\phi_{\text {son- }}\right. \\
\bar{\phi} \\
\text { son })^{2} \\
=1881.011\end{array}$ \\
\hline
\end{tabular}


Am. J. Sci. Ind. Res., 2013, 4(3): 261-271

Table:4

Statistical Table showing the calculation of Standard deviation for NeutronDensity Log of Well A

\begin{tabular}{|c|c|c|c|c|c|c|c|}
\hline $\begin{array}{c}\text { Class } \\
\text { Interval (\%) }\end{array}$ & $\mathrm{F}$ & $(\%)$ & $\mathrm{F}_{\phi_{\mathrm{ND}}(\%)}$ & $\bar{\phi}_{\mathrm{ND}}(\%)$ & $\begin{array}{c}\left(\phi_{\mathrm{ND}}-\bar{\phi}_{\mathrm{ND}}\right) \\
(\%)\end{array}$ & $\begin{array}{c}\left(\phi_{\mathrm{ND}}-\bar{\phi}_{\mathrm{ND}}\right)^{2} \\
\left(\%^{2}\right)\end{array}$ & $\begin{array}{c}\left.\overline{(}_{\mathrm{ND}-} \bar{\phi}_{\mathrm{ND}}\right)^{2} \\
\left(\%{ }^{2}\right)\end{array}$ \\
\hline \hline $20-24$ & 3 & 22 & 66 & 31.69 & -9.69 & 93.896 & 281.688 \\
\hline $25-29$ & 46 & 27 & 1242 & 31.69 & -4.69 & 21.996 & 1011.816 \\
\hline $30-34$ & 46 & 32 & 1472 & 31.69 & 0.31 & 0.096 & 4.416 \\
\hline $35-39$ & 29 & 37 & 1073 & 31.69 & 5.31 & 28.196 & 817.684 \\
\hline $40-44$ & 6 & 42 & 252 & 31.69 & 10.31 & 106.296 & 637.776 \\
\hline $45-49$ & 1 & 47 & 47 & 31.69 & 15.31 & 234.396 & 234.396 \\
\hline & $\begin{array}{c}\sum \mathrm{F} \\
=131\end{array}$ & $\begin{array}{c}\sum \mathrm{F} \phi_{\mathrm{ND}} \\
=4152\end{array}$ & & & & $\begin{array}{c}\sum \mathrm{F}\left(\phi_{\mathrm{ND}}\right. \\
\bar{\phi} \\
\end{array}$ \\
\hline
\end{tabular}

Table.5:

Statistical Table showing the calculation of Standard deviation for Sonic Log of Well B

\begin{tabular}{|c|c|c|c|c|c|c|c|}
\hline $\begin{array}{c}\text { Class } \\
\text { Interval } \\
(\%)\end{array}$ & $\mathrm{F}$ & $\phi_{\text {son }}(\%)$ & $\mathrm{F} \phi_{\text {son }}(\%)$ & $\begin{array}{c}\bar{\phi}_{\text {sonic }} \\
(\%)\end{array}$ & $\begin{array}{c}\left(\phi_{\text {son }}-\bar{\phi}_{\text {son }}\right) \\
(\%)\end{array}$ & $\begin{array}{c}\left(\phi_{\text {son }}-\bar{\phi}_{\text {son }}\right)^{2} \\
\left(\%^{2}\right)\end{array}$ & $\begin{array}{c}F\left(\phi_{\text {son }-}\right. \\
\bar{\phi} \text { son })^{2}\left(\%^{2}\right)\end{array}$ \\
\hline $25-29$ & 3 & 27 & 81 & 41.05 & -14.05 & 197.46 & 592.2 \\
\hline $30-34$ & 10 & 32 & 320 & 41.05 & -9.05 & 81.90 & 819 \\
\hline $35-39$ & 6 & 37 & 222 & 41.05 & -4.05 & 16.40 & 98.4 \\
\hline $40-44$ & 11 & 42 & 462 & 41.05 & 0.95 & 0.90 & 9.9 \\
\hline $45-49$ & 4 & 47 & 188 & 41.05 & 5.95 & 35.40 & 141.6 \\
\hline $50-54$ & 2 & 52 & 104 & 41.05 & 10.95 & 119.90 & 239.8 \\
\hline $55-59$ & 5 & 57 & 285 & 41.05 & 15.95 & 254.40 & 1272 \\
\hline \multirow[t]{2}{*}{$60-64$} & 1 & 62 & 62 & 41.05 & 20.95 & 438.96 & 438.9 \\
\hline & $\begin{array}{c}F \\
=42\end{array}$ & & $\begin{array}{r}\sum \mathrm{F} \phi_{\text {son }} \\
=1,724\end{array}$ & & & & $\begin{array}{l}\sum \mathrm{F}\left(\phi_{\text {son- }}\right. \\
\bar{\phi} \\
\text { son })^{2} \\
=3611.8\end{array}$ \\
\hline
\end{tabular}

Table 6:

Statistical Table showing the calculation of Standard deviation for NeutronDensity Log of Well B

\begin{tabular}{|c|c|c|c|c|c|c|c|}
\hline $\begin{array}{c}\text { Class } \\
\text { Interval } \\
(\%)\end{array}$ & $F$ & $\bar{\phi}_{\mathrm{ND}}(\%)$ & $F_{\phi_{\mathrm{ND}}(\%)}$ & $\bar{\phi}_{\mathrm{ND}}(\%)$ & $\begin{array}{c}\left(\phi_{\mathrm{ND}}-\bar{\phi}_{\mathrm{ND}}\right) \\
(\%)\end{array}$ & $\begin{array}{c}\left(\phi_{\mathrm{ND}}-\bar{\phi}_{\mathrm{ND}}\right)^{2} \\
\left(\%^{2}\right)\end{array}$ & $\begin{array}{c}\mathrm{F}\left(\phi_{\mathrm{ND}}-\bar{\phi}_{\mathrm{ND}}\right)^{2} \\
\left(\%^{2}\right)\end{array}$ \\
\hline \hline $20-24$ & 3 & 22 & 66 & 30.8 & -8.8 & 77.44 & 232.32 \\
\hline $25-29$ & 12 & 27 & 324 & 30.8 & -3.8 & 14.44 & 173.28 \\
\hline $30-34$ & 20 & 32 & 608 & 30.8 & 1.2 & 1.44 & 27.36 \\
\hline $35-39$ & 8 & 37 & 296 & 30.8 & 6.2 & 38.44 & 307.52 \\
\hline & $\begin{array}{c}\sum \mathrm{F} \\
=42\end{array}$ & $\begin{array}{c}\sum \mathrm{F} \phi_{\mathrm{ND}} \\
=1294\end{array}$ & & & & $\begin{array}{c}\sum \mathrm{F}\left(\phi_{\mathrm{ND}-} \bar{\phi}_{N D}\right)^{2} \\
=740.48\end{array}$ \\
\hline
\end{tabular}


Am. J. Sci. Ind. Res., 2013, 4(3): 261-271

Table 7: Showing the Range, Mean Porosity Values, Standard Deviation and Coefficient of Variation for both Wells $A$ and $B$

\begin{tabular}{|l|c|c|c|c|}
\hline \multirow{2}{*}{ Statistical parameter } & \multicolumn{2}{|c|}{ WELL A } & \multicolumn{2}{c|}{ WELL B } \\
\cline { 2 - 5 } & $\phi_{\text {son }}(\%)$ & $\phi_{\text {ND }}$ & $\phi_{\text {son }}(\%)$ & $\phi_{\text {ND }}$ \\
\hline Range & 35 & 26 & 34 & 19 \\
\hline Mean & 6.96 & 31.69 & 41.05 & 30.80 \\
\hline Standard deviation & 3.79 & 4.77 & 9.27 & 4.20 \\
\hline Coefficient of Variation & 56.70 & 15.05 & 22.58 & 13.64 \\
\hline
\end{tabular}

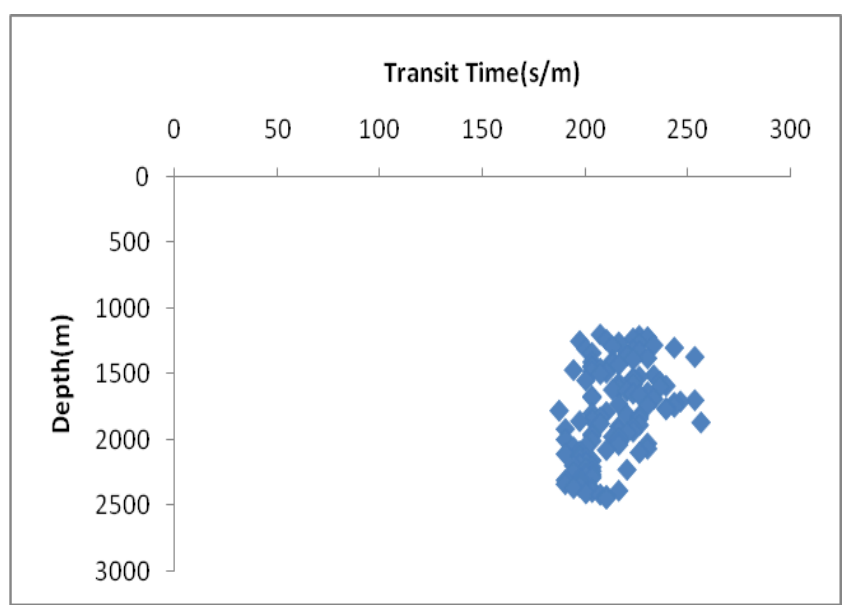

Fig.1: Depth-transit time profile for Well A

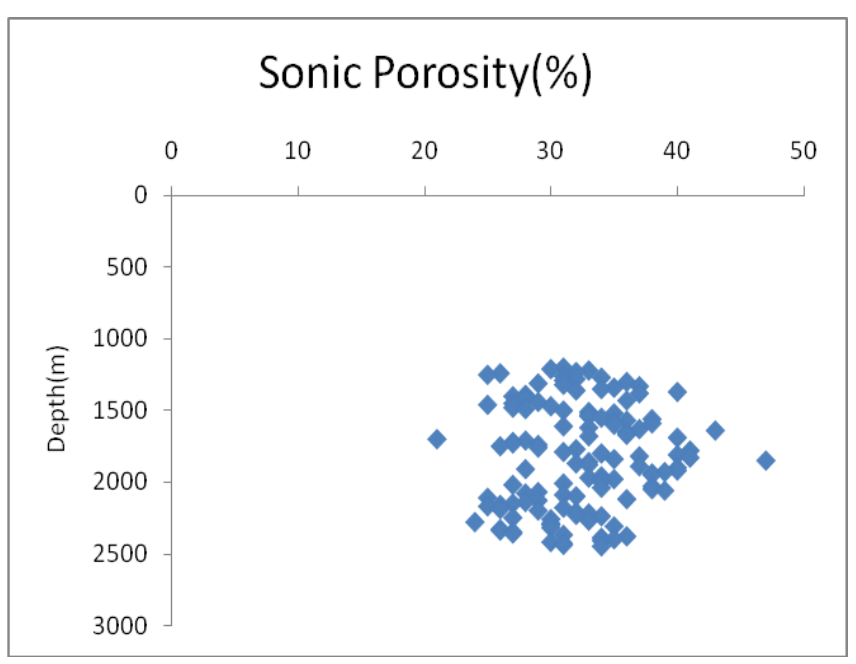

Fig. 2: Depth-Sonic-derived porosity profile for Well A 
Am. J. Sci. Ind. Res., 2013, 4(3): 261-271

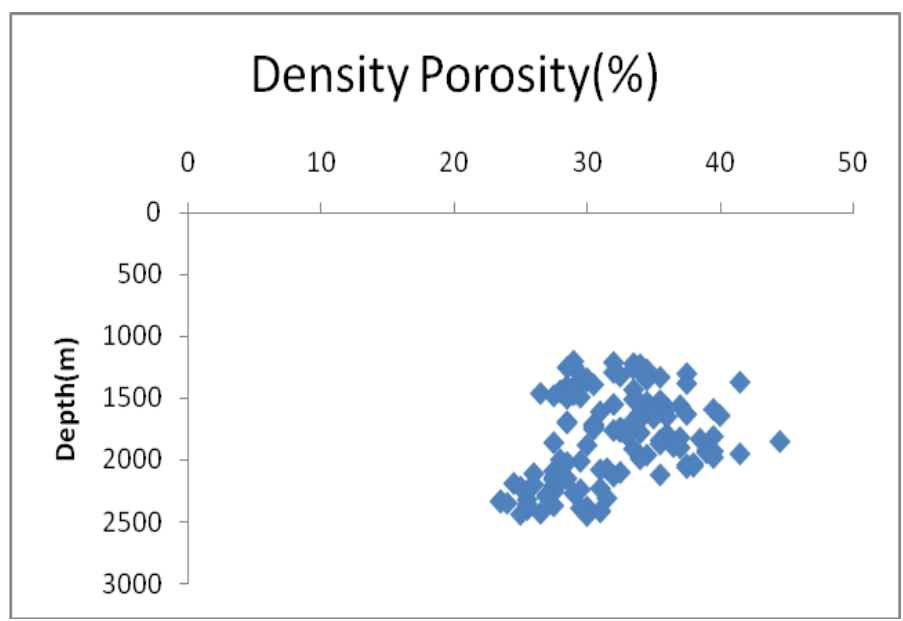

Fig. 3: Depth-density-derived porosity profile for Well A

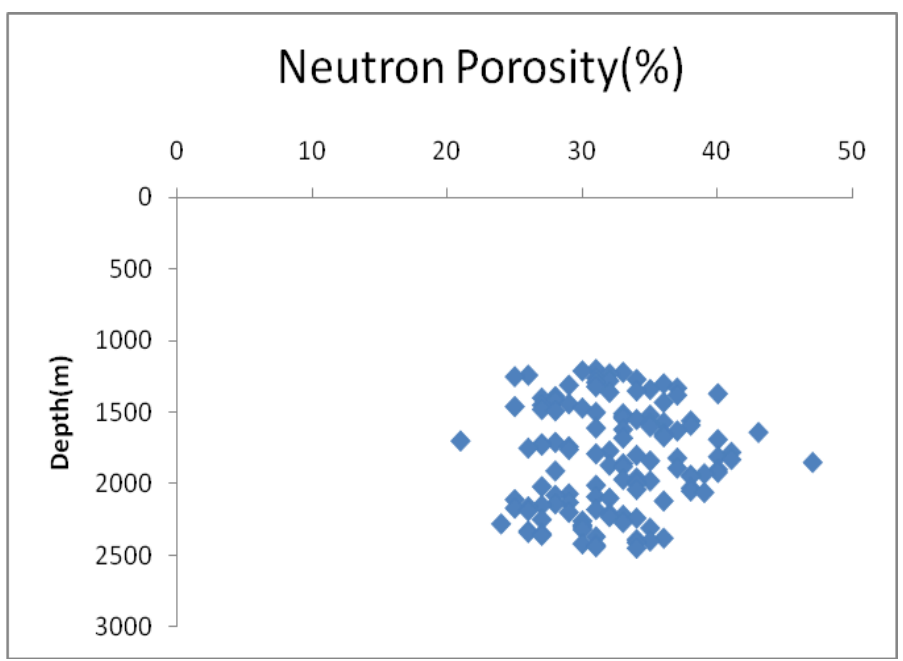

Fig. 4: Depth-neutron-derived porosity profile for Well A

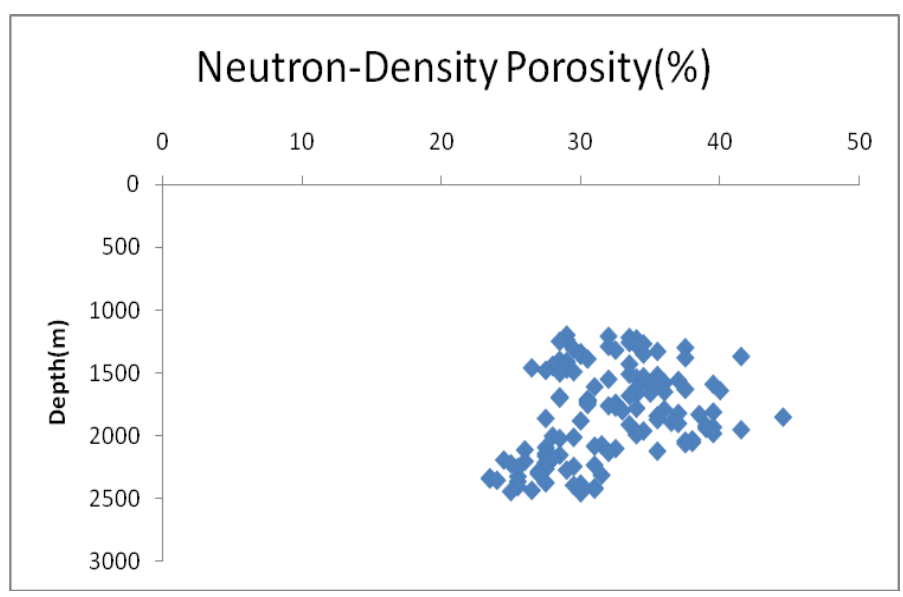

Fig. 5: Depth-neutron-density-derived porosity profile for Well A 
Am. J. Sci. Ind. Res., 2013, 4(3): 261-271

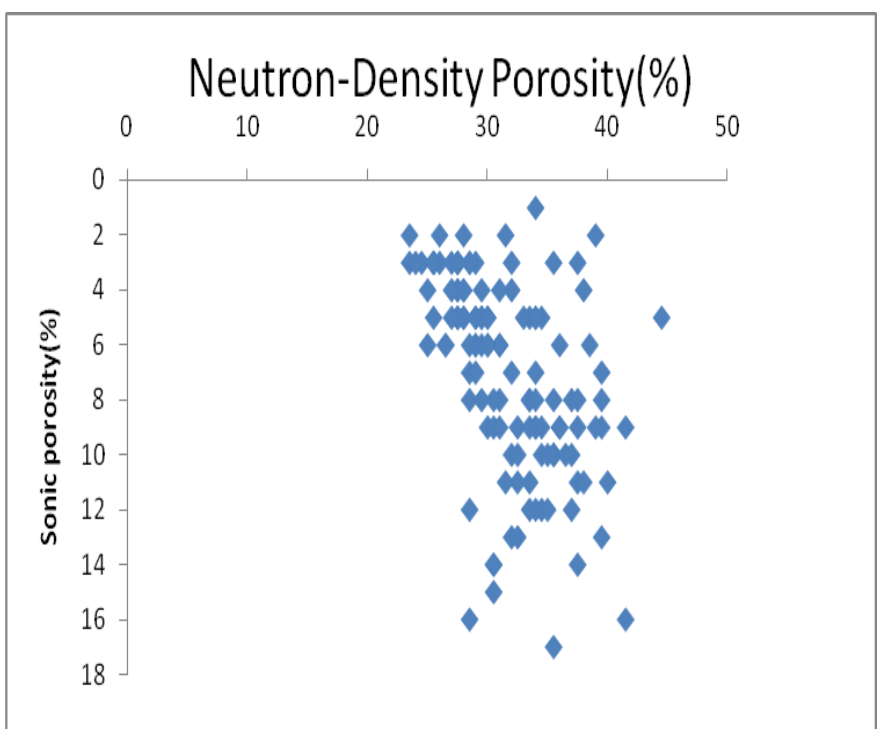

Fig. 6: Sonic porosity-neutron-density derived porosity profile for Well A

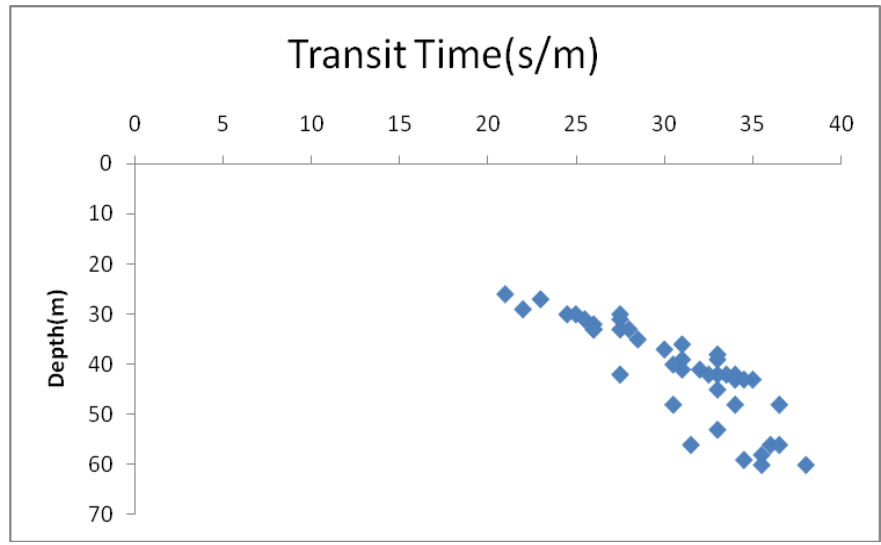

Fig. 7: Depth-transit-time profile for Well B

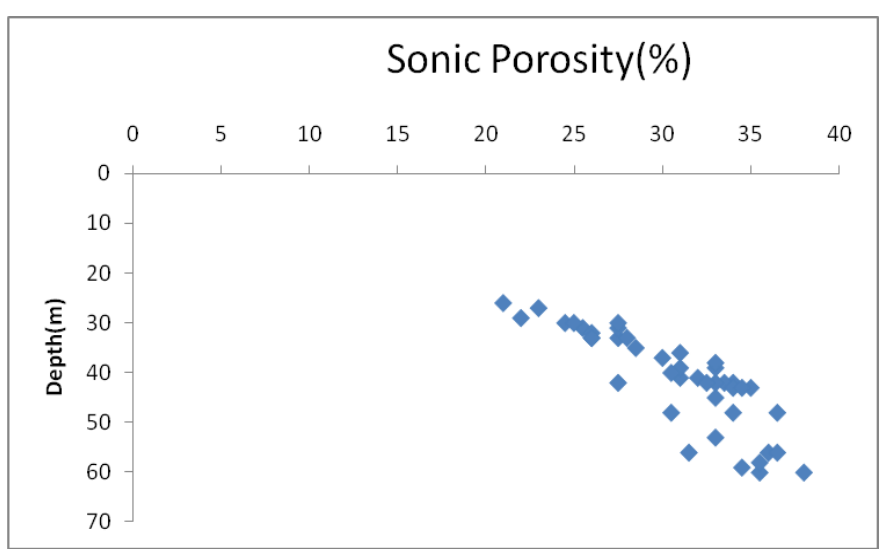

Fig. 8: Depth-sonic-derived porosity profile for Well B 
Am. J. Sci. Ind. Res., 2013, 4(3): 261-271

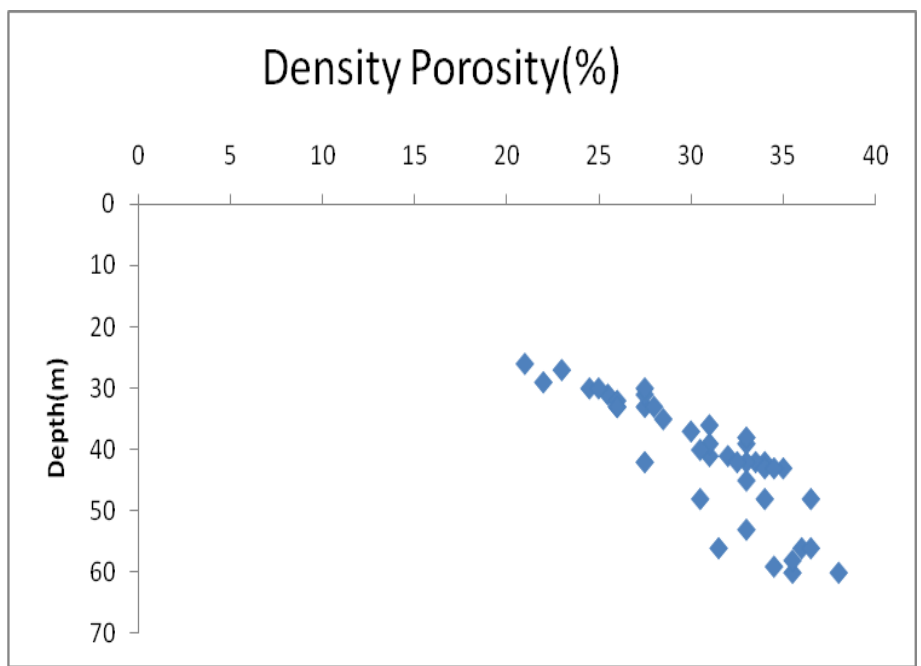

Fig. 9: Depth-density-derived porosity profile for Well B

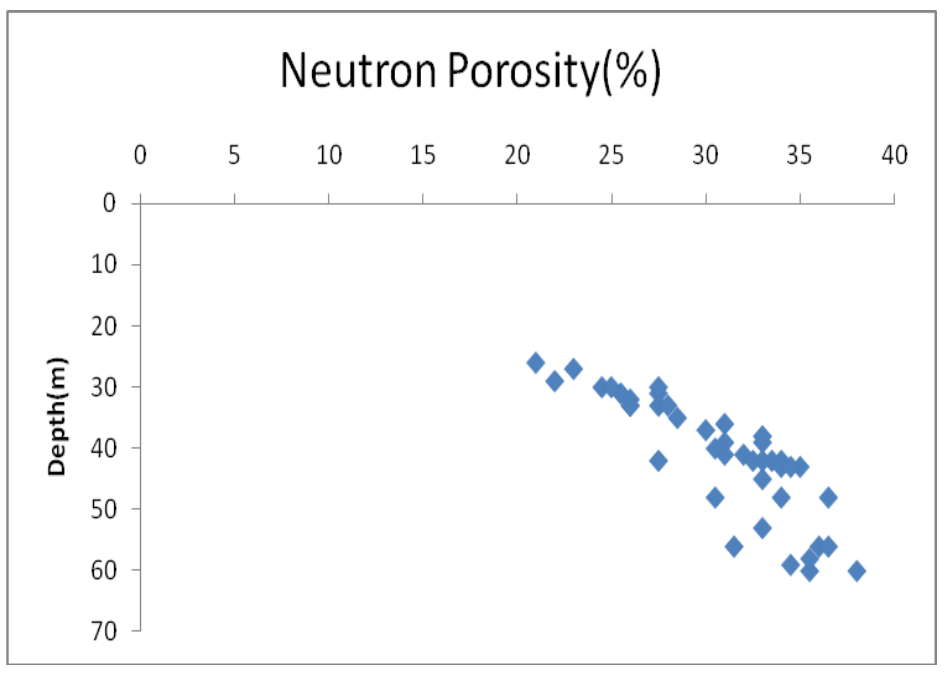

Fig. 10: Depth-neutron-derived porosity profile for Well B

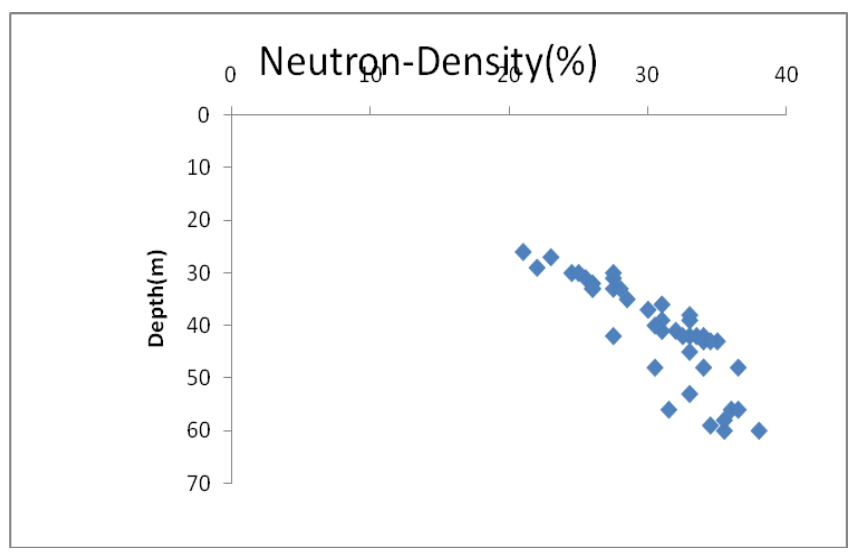

Fig. 11: Depth-neutron-density-derived porosity profile for Well B 


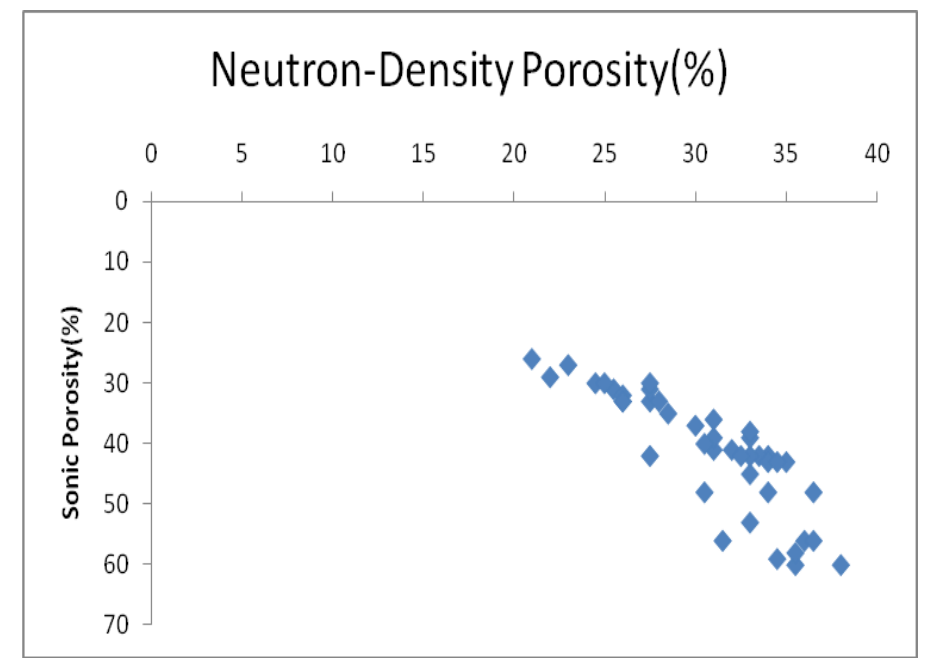

Fig.12: Sonic-porosity-neutron-density-derived porosity profile for Well B.

CONCLUSION: The objective of this project is to compare and determine the most reliable logging tool between sonic log and neutron-density log for the derivation of the porosity of a formation using statistical analysis. Therefore, from the result of this study, the following observations and conclusions are reached:

1. For sonic log of well A porosity values computed varies between $17 \%$ at depth $1870 \mathrm{~m}$ and $4 \%$ at depth $2470 \mathrm{~m}$ while neutron-density porosity values computed of the same well $A$ varies between $36 \%$ and $27 \%$ at the same depth, and for sonic log of well B porosity values computed varies between $60 \%$ at depth $1510 \mathrm{~m}$ and $30 \%$ at depth $1160 \mathrm{~m}$ while neutron-density porosity values computed of the same well $B$ varies between $38 \%$ and $25 \%$ at the same depth.

2. Transit time decreases with depth but varies at some depth due to changes in lithology, vuggy pores and abnormal pressure zone.

3. Bulk density increases with depth but varies at some depth due to changes in lithology and abnormal pressure zone.

4. Porosity of rocks generally/ decreases with depth for sonic and neutron-density logs in all wells.

5. Computation of Coefficient of variation for sonic and neutron-density derived porosity values shows that, for well $A$, and well $B$ the coefficient of variation for sonic log derived porosities are $56 \%$, and $23 \%$ respectively, while the coefficient of variation for neutron-density log derived porosities are $15 \%$, and $14 \%$ for the same wells respectively.
6. Coefficient of variation of Neutron-density log derived porosities is less than sonic log derived porosities. Therefore Neutron-density log derived porosity is more reliable porosity data than sonic log derived porosity.

7. The minimum tool combination recommended for determination of a reliable porosity of a formation should be the neutron and density logging tool.

ACKNOWLEDGMENT: We are very grateful to Shell Petroleum Development Company of Nigeria for provision of data.

\section{REFERENCES}

Avseth, P., Mukerji, T and Mavko, G (2005). Quantitative Seismic Interpretation. Cambridge University Press, United Kingdom, pp. 2 - 25

Dewan, J. T (1983). Essentials of Modern Open-Hole Log Interpretation, PennWell Corporation Tulsa, Oklahoma USA, pp. 95 - 197.

Edward H. I and Srivastava, R. M (1989). An introduction to applied geostatistics. Oxford University Press, New York, USA, pp. 11 - 21

Etu-Efeotor, J. O (1997). Fundamentals of Petroleum Geology. Paragraphics, Port Harcourt, Nigeria, pp. 110 -124 .

Keary, P., Brooks, M and Hill, I (2002). An Introduction to Geophysical Exploration, $3^{\text {rd }}$ Ed. T. J. International, Pad Stow, Cornwell.

Moriss, H. DeGroot (1975). Probability and statistics. Addison Wesley Pub. Co.

Murray R. S., John, Schiller, J and Srinivasan, R. A (1975). Schaum's outline of theory and problems of probability and statistics $2^{\text {nd }}$ edition. McGraw-Hill. 
Am. J. Sci. Ind. Res., 2013, 4(3): 261-271

Prem, V. S (1997). Environmental and Engineering Geophysics. Cambridge University Press, London.

Schlumberger, $2000 . \quad$ Log Interpretation: Principles/Applications. Schlumberger Education Services.

Sheriff, R. E., 1991. Encyclopedic Dictionary of Exploration Geophysics; $3^{\mathrm{RD}}$ Ed. Society of Exploration Geophysicist, USA.
Telford, W. M., Geldart, L. P and Sheriff, R. E (1990). Applied Geophysics, Cambridge University Press, Cambridge. London, pp. 283 -292

Wyllie, M. R. J (1963) The Fundamentals of well Log Interpretation. Academic Press, New York. 